\title{
ОСНОВНІ НАПРЯМИ ВЗАЄМОДІЇ СЛІДЧИХ З ІНШИМИ ПІДРОЗДІЛАМИ НАЦІОНАЛЬНОЇ ПОЛІЦІї У ПРОТИДІї НЕЗАКОННОМУ ОБІГУ НАРКОТИЧНИХ ЗАСОБІВ
}

Возіян В. A.

Стаття присвячена дослідженню основних напрямів взаємодії слідчих з іншими підрозділами Національної поліціі у протидії незаконному обігу наркотичних засобів. Визначається зміст та сутність взаємодіі, їі основні форми. Зазначено, що прочесуальна форма взаємодії здійснюється відповідно до положень КПК України, а організаційна - відповідно до міжвідомчих та відомчих нормативних актів МВС України. Визначаються основні принципи взаємодіі під час досудового розслідування кримінальних правопорушень. Звертається увага на те, що взаємодія між слідчим і іншими підрозділами поліціі може бути й на стадії судового розгляду матеріалів кримінальних проваджень.

Ключові слова: органи досудового розслідування, оперативні підрозділи, експерти, суд, кримінальне провадження, взаємодія, процесуальна форма взаємодіі, організачійна форма взаємодіі, слідчо-оперативна група, доручення слідчого, слідча (розшукова) дія.

Статья посвящена исследованию основных направлений взаимодействия следователей и подразделений Национальной полиции Украины при расследовании криминальных правонарушений в сфере незаконного оборота наркотиков. Определяется содержание, сущность взаимодействия и его основные формы. Подчеркивается, что процессуальная форма взаимодействия осуществляется в соответствии с нормами КПК Украины, а организационная - с нормами межведомственных и ведомственных нормативных актов МВД Украины. Определяются основные принципы взаимодействия во время досудебного расследования уголовных правонарушений. Обращается внимание на то, что взаимодействие следователей с другими подразделениями полиции может быть и на стадии судебного рассмотрения материалов уголовных производств.

Ключевые слова: органы досудебного расследования, оперативные подразделения, эксперты, суд, уголовное производство, взаимодействие, процессуальная форма взаимодействия, организационная форма взаимодействия, следственно-оперативная группа, поручение следователя, следственное (разыскное) действие.

The article is devoted to the study of the main directions of interaction of investigators with other units of the National Police in combating drug trafficking. The content and essence of interaction, its main forms are determined. It is stated that the procedural form of interaction is carried out in accordance with the provisions of the CPC of Ukraine and provides for: execution by the operational unit of investigative (investigative) actions and unspoken investigative (investigative) actions on behalf of the investigator; transfer to the investigator of materials of operational-search activity on the facts of criminal offenses; participation of employees of other units in the conduct of individual investigative (search) actions; taking measures to locate the suspect after the pre-trial investigation is terminated.

Возіян В. А., 2019
On the basis of the analysis of interagency and departmental normative acts of the Ministry of Internal Affairs of Ukraine, organizational forms of interaction are revealed, which are manifested during: joint work in the composition of investigative-operative groups that ensure the integrated use of the forces and means of the units of the investigation, operatives, inspectors-criminologists and other services under the leadership investigator; mutual exchange of information between the investigator and other units of the National Police; conducting joint investigative actions and measures during the pre-trial investigation and judicial review of the materials of criminal proceedings. Attention is drawn to the fact that interaction between the investigator and other police units may also be at the stage of judicial review of criminal proceedings, when, in order to verify and clarify the facts obtained during the trial, the court has the right to instruct the investigating authority, to carry out certain investigators (search), incl. unspoken investigative (search) actions or upon receipt of a court order announcing the search of the accused.

The basic principles of interaction during the pre-trial investigation of criminal offenses are determined, namely: fast, complete and impartial investigation of criminal offenses; independence of the investigator in the proceedings; making optimum use of the available capabilities of pre-trial authorities and other police units; adherence to the general principles of criminal proceedings; ensuring the non-disclosure of pre-trial investigation data.

Key words: bodies of pre-trial investigation, operational units, experts, court, criminal proceedings, interaction, procedural form of interaction, organizational form of interaction, investigative-operational group, commission of investigator, investigative (investigative) action.

Постановка проблеми та їі актуальність. У сучасних умовах протидії злочинності в Україні незаконний обіг наркотичних засобів набуває загрозливих масштабів та має виражений організований характер. Ситуація характеризується появою на ринку різних за психоактивною дією видів наркотичних засобів та психотропних речовин, розгалуженням злочинного наркобізнесу, що містить у собі шкоду для здоров'я населення країни та виступає одним із головних чинників загострення криміногенної обстановки в цілому. Ефективно протистояти зазначеним викликам можна лише за умови тактично і методично налагодженого співробітництва та організації взаємодії між слідчими та іншими органами і підрозділами Національної поліції.

Аналіз останніх досліджень і публікацій. Окремим аспектам взаємодії під час виявлення та розслідування злочинів, у тому числі в сфері незаконного обігу наркотичних засобів, приділено увагу у працях К.В. Антонова, В.П. Бахіна, В.Д. Берназа, М.П. Водька, А.Ф. Волобуєва, А.М. Волощука, Е.О. Дідоренка, А.В. Іщенка, Д.Й. Никифорчука, М.А. Погорець- 
кого, О.П. Снігерьова, В.Є. Тарасенка, В.Ю. Шепітька та інших вчених. Водночас слід відзначити, що сьогодні існують певні особливості взаємодії органів досудового розслідування з іншими підрозділами під час розслідування наркозлочинів.

У юридичній літературі взаємодія розглядається як узгоджена діяльність слідчого, оперуповноваженого, спеціаліста та експерта, спрямована на вирішення завдань з виявлення, розкриття, розслідування злочинів та запобігання злочинам [7; 8]. Як правило, автори виділяють процесуальні та організаційні форми взає модії [7; 8; 9]. Вважається, що процесуальна взаємодія регламентується кримінальним процесуальним законом, а організаційна - відомчими нормативними актами. Форма взаємодії як спосіб організації включає в себе комплекс способів та прийомів взаємодії, систему зв'язків і правовідносин взаємодіючих суб'єктів.

Мета статті - охарактеризувати основні напрями взаємодії слідчих з іншими підрозділами національної поліції у протидії незаконному обігу наркотичних засобів.

Виклад основного матеріалу. Розглядаючи особливості взаємодії у протидії незаконному обігу наркотиків, слід відзначити, що вона, як правило, починається з передачі слідчому матеріалів оперативно-розшукової діяльності. Відповідно до положень КПК України матеріали, зібрані оперативними підрозділами згідно 3 вимогами Закону «Про оперативно-розшукову діяльність», $\epsilon$ документами та можуть використовуватися у кримінальному провадженні як докази [2, ч. 2 ст. 99]. Відомчі нормативні акти [5, розд. 3] регламентують можливість ознайомлення слідчого 3 оперативними матеріалами з метою їхньої оцінки. У разі необхідності створюється слідчо-оперативна група з залученням до ії складу досвідчених слідчих і оперативних працівників. Під час спільної діяльності вирішуються питання щодо реалізації матеріалів оперативно-розшукової діяльності, внесення відомостей до Єдиного реєстру досудових розслідувань, а також можливості використання отриманих фактичних даних у кримінальному провадженні.

У плані заходів з реалізації матеріалів оперативно-розшукової діяльності з виявлення фактів збуту наркотичних засобів повинні бути передбачені такі дані:

1) місце і час проведення оперативної закупки;

2) задіяні сили та засоби для фіксації оперативної закупки, у тому числі відеозапис;

3) розподіл дій залучених працівників поліції;

4) інші послідовні дії працівників оперативних підрозділів (з урахуванням специфіки злочину) [5, розд. 11].

При направленні до органів досудового розслідування матеріалів за результатами проведення оперативно-розшукових заходів одночасно надається інформація про проведені оперативними підрозділами заходи з розшуку майна і коштів, на які може бути накладений арешт, та про їх місцезнаходження [5, п. 2 розд. 11].

Після початку досудового розслідування взаємодія слідчих з іншими підрозділами поліції здійснюється в межах кримінальних проваджень. Слідчий у кожному кримінальному провадженні про незаконний збут наркотичних засобів проводить всі можливі та необхідні слідчі (розшукові) дії та негласні слідчі (розшукові) дії, спрямовані на повне, всебічне та неупереджене документування джерел отримання наркотичних засобів, використання коштів, здобутих від незаконного обігу наркотичних засобів, а не лише факту збуту нарко- тичних засобів. Виключно за результатами отримання доказів, які свідчать про збут наркотичних засобів, за наявності для цього належних підстав слідчий ініціює питання про проведення контролю за вчиненням злочину у формі оперативної закупки [5, п. 7 розд. 11].

Згідно з чинним КПК слідчий органу досудового розслідування уповноважений доручати проведення слідчих (розшукових) дій та негласних слідчих (розшукових) дій відповідним оперативним підрозділам [2, ч. 3 ст. 40]. Вони $\epsilon$ обов'язковими для виконання i надсилаються начальнику оперативного підрозділу у письмовій формі, де повинні бути чітко сформульовані питання, які належить з'ясувати, і має бути викладена інформація, необхідна для виконання доручення [2, ст. 41]. Керівник оперативного підрозділу, що отримав доручення, за погодженням зі слідчим, що надав доручення, зобов'язаний в найкоротший строк організувати виконання зазначеного доручення [2, ч. 6 ст. 232]. Під час виконання доручень слідчого працівник оперативного підрозділу користується повноваженнями слідчого [2, ч. 2 ст. 41].

Працівники інших підрозділів також можуть брати безпосередню участь у проведенні окремих слідчих (розшукових) дій. Найчастіше слідчий їх залучає при реагуванні на заяви і повідомлення про кримінальні правопорушення у сфері незаконного обігу наркотиків до проведення таких слідчих (розшукових) дій, як огляд місцевості, приміщення, речей, документів (ст. 237 КПК), а також до проведення опитування громадян, які проживають неподалік від місця події, обстеження прилеглої території для виявлення осіб, причетних до вчинення наркозлочинів, свідків, потерпілих тощо. Їхня допомога може бути використана під час проведення обшуку (ст. 234 КПК) з метою забезпечення сприятливих умов для його проведення та забезпечення безпеки учасників обшуку, під час затримання особи, яка збуває наркотики, без ухвали слідчого судді, суду (ст. 207, 208 КПК), а також під час тимчасового вилучення майна (ст. 167, 168 КПК), проведення слідчого експерименту (ст. 240 КПК), коли потрібна допомога у відтворенні обстановки певної події.

Слідчий при проведенні огляду місця події або обшуку під час досудового розслідування кримінального правопорушення, пов'язаного з незаконним обігом наркотичних засобів, самостійно (чи за його дорученням спеціаліст) в установленому КПК України порядку застосовує відеофіксацію цих слідчих (розшукових) дій та складає плани-схеми, а також вилучає необхідні речі, предмети та документи [5, п. 3 розд. 11]. Участь працівників інших підрозділів засвідчується відповідним записом у протоколі слідчої (розшукової) дії.

У кримінальному провадженні про незаконний обіг наркотичних засобів упродовж доби після вилучення наркотичних засобів слідчий виносить постанову про призначення експертизи та направляє іï з відповідними додатками для виконання до державної спеціалізованої установи, що здійснює судово-експертну діяльність, та забезпечує направлення до експертної установи матеріалів, необхідних для проведення судової експертизи. За необхідності слідчий порушує клопотання перед керівником експертної установи про вжиття заходів щодо невідкладного проведення судової експертизи та отримання відповідного висновку [5, п. 8 розд. 11]. 
Взаємодія відбувається і після зупинення досудового розслідування, якщо потрібно встановити місцезнаходження підозрюваної особи. Якщо підозрюваний у вчиненні наркозлочинів переховується від органів слідства та суду з метою ухилення від кримінальної відповідальності, а його місцезнаходження невідоме, то досудове розслідування може бути зупинене, а слідчий оголошує його розшук [2, ч. 2 ст. 280]. Про оголошення розшуку виноситься окрема постанова, а здійснення розшуку підозрюваного доручається оперативним підрозділам [2, ч. 2 ст. 281].

Варто звернути увагу на те, що взаємодія між слідчим і оперативними підрозділами може бути не лише на стадії досудового розслідування, але й на стадії судового розгляду матеріалів кримінальних проваджень за фактами наркозлочинів. Так, з метою перевірки та уточнення фактичних даних, отриманих в ході судового розгляду, суд має право доручити органу, що проводив розслідування, виконати певні слідчі (розшукові), у т.ч. негласні слідчі (розшукові) дії [2, ч. 3 ст. 333]. Окрім цього, за дорученням начальника слідчого підрозділу, до якого надійшла ухвала суду про оголошення розшуку обвинуваченого [2, ст. 335], для організації виконання розшуку в установленому законодавством порядку працівник оперативного підрозділу заводить відповідну оперативно-розшукову справу та здійснює розшукові заходи з метою встановлення місцезнаходження обвинуваченого.

Що стосується організаційної форми взаємодії слідчого з іншими підрозділами у протидії незаконному обігу наркотиків, то вона $є$ похідною від процесуальної та нерозривно пов'язаною з нею. Регламентація напрацьованих практикою організаційних форм взаємодії під час розкриття та розслідування злочинів, не передбачених процесуальним законодавством, набула свого розвитку у різних відомчих нормативно-правових актах. Зокрема, згідно з Інструкцією з організації взаємодії органів досудового розслідування 3 іншими органами та підрозділами Національної поліції України в запобіганні кримінальним правопорушенням, їх виявленні та розслідуванні [5, п. 1] основним завданням взаємодії $€$ попередження, виявлення і розслідування кримінальних правопорушень, притягнення до встановленої законодавством відповідальності осіб, що їх учинили, відшкодування завданої кримінальними правопорушеннями шкоди, відновлення порушених прав та інтересів громадян і юридичних осіб. У цьому нормативно-правовому акті сформульовані основні напрями взаємодії слідчого й оперативного співробітника, які характерні для розслідування наркозлочинів.

Аналіз відомчих нормативних актів дозволяє до організаційних форм взаємодії віднести спільну роботу у складі слідчо-оперативної групи. Керівник органу досудового розслідування з метою забезпечення всебічного, повного i неупередженого розслідування кримінальних правопорушень у сфері обігу наркотичних засобів ініціює перед керівником територіального органу, підрозділу поліції створення СОГ, до складу якої включаються працівники органу досудового розслідування та оперативних підрозділів, які мають досвід розслідування кримінальних правопорушень цієї категорії (у разі вчинення тяжких та особливо тяжких злочинів це відбувається одночасно із внесенням інформації до ЄРДР, а в кримінальних провадженнях про злочини невеликої та середньої тяжкості - за необхідності), погоджує створення СОГ [5, п. 4 розд. 11]. Зі свого боку керівник оперативного підрозділу, оперативний працівник якого включений до складу СОГ або за матеріалами якого розпочате кримінальне провадження, забезпечує взаємодію з органом досудового розслідування Національної поліції України, який здійснює розслідування злочинів у сфері обігу наркотичних засобів [5, п. 6 розд. 11].

Взаємодія у складі СОГ полягає у представленні один одному інформації у сфері незаконного обігу наркотиків, отриманої в процесі пошукових і слідчих дій, яка становить взаємний інтерес. Передача такої інформації може здійснюватися як в усній, так і в письмовій формі. Це дозволяє погоджувати, координувати сумісні дії згідно з отриманою інформацією та спрямовувати зусилля на з'ясування тих обставин, що підлягають дослідженню в межах кримінального провадження [5, п. п. 4, 5]. Ознайомлення слідчого з отриманими даними допомагає йому краще уявити картину злочину, глибше з'ясувати механізм злочинних дій у сфері незаконного обігу наркотиків, точніше визначити роль кожного співучасника і намітити найбільш раціональні шляхи розслідування.

Окрім цього, у складі СОГ можуть бути проведені спільні розшукові дії та заходи як під час досудового слідства, так і під час судового розгляду матеріалів кримінальних проваджень. Взаємодія у цій формі, як правило, проявляється у проведенні відповідних дій, заходів, тактичних комбінацій, що спрямовані на розкриття злочинів, розшук підозрюваних, нейтралізацію протидії досудовому розслідуванню та відправленню правосуддя, забезпечення безпеки учасників кримінального судочинства, забезпечення відшкодування заподіяної злочином матеріальної шкоди і можливої конфіскації майна тощо.

Керівник органу досудового розслідування повинен щомісяця розглядати на оперативних нарадах за участю керівника територіального органу, підрозділу поліції та керівників структурних підрозділів результати роботи з виявлення осіб, які вчинили кримінальні правопорушення у сфері обігу наркотичних засобів, а стан досудового розслідування в кримінальних провадженнях про тяжкі та особливо тяжкі злочини цієї категорії, які викликали суспільний резонанс, він має аналізувати щотижня [5, п. 4 розд. 11].

Висновки. Підсумовуючи значене, ми дійшли висновку, що взаємодія органів досудового розслідування з іншими підрозділами Національної поліції України у сфері незаконного обігу наркотиків являє собою узгоджену за часом, місцем і метою спільну діяльність, що здійснюється відповідно до кримінального процесуального законодавства, підзаконних та відомчих нормативних актів, що регламентують створення та роботу у складі слідчо-оперативних груп в межах кримінальних проваджень за фактами тяжких та особливо тяжких наркозлочинів, використання матеріалів ОРД як підстав для початку досудового розслідування та доказів у кримінальному провадженні, виконання іншими підрозділами доручень слідчих, проведення заходів безпеки учасниками кримінального судочинства та інші взаємини слідчих з працівниками підрозділів Національної поліції на усіх стадіях кримінального процесу. 


\section{Література}

1. Конституція України : Закон України від 28 червня 1996 p. URL: http://zakon1.rada.gov.ua (дата звернення: 05.09.2019).

2. Кримінальний процесуальний кодекс України : Закон України від 13 квітня 2012 p. URL: http://zakon2.rada.gov. иа (дата звернення: 05.09.2019).

3. Про Національну поліцію : Закон України від 02 липня 2015 p. URL: http: / /zakon4.rada.gov.ua (дата звернення: 05.09.2019).

4. Про оперативно-розшукову діяльність : Закон України від 18 лютого 1992 р. URL: http://zakon2.rada.gov.ua (дата звернення: 05.09.2019).

5. Про затвердження Інструкції з організації взаємодії органів досудового розслідування з іншими органами та підрозділами Національної поліції України в запобіганні кримінальним правопорушенням, їх виявленні та розслідуванні : наказ MBC України № 575 від 07 серпня 2017 р. URL: http: //zakon2.rada.gov.ua (дата звернення: 05.09.2019).

6. Про організацію діяльності органів досудового розслідування Національної поліції України : наказ МВС України

Протидія злочинності: проблеми практики та науково-методичне забезпечення

№ 570 від 06 липня 2017 р. URL: http://zakon2.rada.gov.ua (дата звернення: 05.09.2019).

7. Тарасенко В.Є., Головін Д.В., Поліщук О.В. Взаємодія органів досудового розслідування з іншими органами і підрозділами Національної поліції України в запобіганні, виявленні та розслідуванні злочинів : навчальний посібник. Одеса : ОДУВС, 2017. 104 с.

8. Тарасенко В.Є., Поліщук О.В. Організація взаємодії органів досудового розслідування та оперативних підрозділів при проведенні негласних слідчих (розшукових) дій в межах кримінальних проваджень : метод. рек. Одеса : ОДУВС, 2017. 78 с.

9. Тарасенко В.Є., Тарасенко Р.В. Правові засади діяльності кримінальної поліції в інтересах кримінального судочинства : монографія. Одеса, 2018. 240 с.

Возіян В. А., ад'юнкт денної форми навчання докторантури та аспірантури Одеського державного університету внутрішніх справ 